\title{
Discharge education delivered to general surgical patients in their management of recovery post discharge - a systematic mixed studies review
}

\section{Authors:}

${ }^{*}{ }^{1}$ Evelyn Kang MHealthPrac, RN; ${ }^{12}$ Brigid M. Gillespie PhD RN, FACORN; ${ }^{2}$ Geogia Tobiano PhD, RN, $\&{ }^{1}$ Wendy Chaboyer PhD RN

${ }^{1}$ Menzies Health Institute Qld (MHIQ), Griffith University, Gold Coast Campus QLD, AUSTRALIA

${ }^{2}$ The Gold Coast University Hospital, QLD, AUSTRALIA

\section{Email addresses:}

${ }^{12}$ Brigid Gillespie: b.gillespie@griffith.edu.au

${ }^{2}$ Georgia Tobiano: g.tobiano@griffith.edu.au

${ }^{1}$ Wendy Chaboyer: w.chaboyer@griffith.edu.au

\section{*Corresponding author:}

Evelyn Kang: e.kang@griffith.edu.au

+61755529737

G01_Rm 2.05D, Griffith University

Parklands Dr, Southport

Gold Coast, Qld Australia 4222

\section{Abstract}

Background: Discharge education is essential for postoperative general surgery patients for their self-management of care at home post discharge. The first 30 days' post-surgery is pivotal to the post-operative recovery process as this is when most post-operative complications occur. Insufficient discharge education can compromise patients' recovery process causing postoperative complications and unplanned hospital readmissions. Objectives: To identify the discharge education provided to general surgery patients Design: Systematic mixed studies review

Data sources: Literature data sources were searched from December 2017 to January 2018 using the four databases: EBSCO CINAHL Plus, EBSCO MEDLINE, Ovid EMBASE and COCHRANE Library. Searches were supplemented with hand searching of reference lists. 
Review methods: The relevance of the articles was reviewed using inclusion criteria; included data were extracted and presented in a summary table. Two reviewers appraised the methodological quality of the articles using the Mixed Methods Appraisal Tool. Discussions were held to examine emergent themes, quality scores of the studies, and agreement reached by consensus. Themes were derived through inductive analysis.

Results: A total of 468 records were screened for titles and abstracts and 7 studies met the inclusion criteria. There was a mix of qualitative and quantitative studies. The majority of the included sample were patients with one quantitative study including patients' family and nurses. Discharge education was delivered at various timing and at different doses during the surgical process. Education delivered was mostly standardised and some of the discharge interventions were tailored and included a checklist for stoma care and a discharge warning tool. Four themes were identified: quality of discharge education influences its uptake, health care professionals' perceptions of their role in the delivery of discharge education to patients, patients' preferences for education delivery and patients' participation in their selfcare.

Conclusions: The quality of discharge education has an influence on patient participation in their management of care post discharge. Assessing patients' preparedness for discharge is an essential component of discharge planning process. The presentation, timing and frequency of discharge education was important in the delivery of information. Tailored education reflecting the learning needs of patients using multiple media delivered in varying doses enhanced patients' overall knowledge for successful management of recovery post discharge. The scarcity of recent literature in discharge education indicates that the quantity of evidence regarding discharge education intervention in general surgery patients is low and further work in this area needs to be undertaken.

Keywords: abdominal surgery, discharge education, discharge information, discharge teaching, general surgery, post-operative, review

\section{Contribution to the paper.docx}

\section{What is already known about the topic?}

- Discharge education delivered as an individualised intervention was found to be more beneficial to standardised discharge education interventions. 
- There are mixed results on the impact of patients' understanding of the delivery of discharge education delivered at different timings and doses.

\section{What this paper adds}

- The quality of discharge education influence the extent to which patient participate in their care.

- Health care professionals' perceptions of their role impacts on the delivery of discharge education.

- Who, how, what and when discharge education is delivered is important to patients and has an influence on their recovery.

\section{Introduction}

Post-operative complications from surgical procedures such as bleeding, surgical site infection and gastrointestinal complications are some of the issues general surgery patients face following discharge from hospital (Merkow et al., 2015). Information on self-care and education about the surgery and the strategies to prevent postoperative complications after hospital discharge is crucial as it may enable patients to recognise when professional intervention is required. With improved postoperative education and closer follow up, it is estimated that $50 \%$ of hospital readmissions may be preventable (Dawes et al., 2014).

\subsection{Background}

For surgical patients, management of self-care during the postoperative period is often altered because of pain, fatigue and the presence of a surgical wound (Pieper et al., 2006). Discharge education is critical for post-operative patients to promote their ability to adhere to self-care instructions and regain independence, enhancing their recovery. One of the key functions of discharge education is to prepare patients with the necessary knowledge to participate in their care post discharge (Polster, 2015).

The first 30 days' post-surgery is pivotal to the post-operative recovery process as this is when most post-operative complications occur (Kassin et al., 2012). One in four surgical patients may develop post discharge complications within 14 days after discharge (Kazaure et al., 2012) with about $11.3 \%$ of general surgery patients readmitted within 30 days of 
discharge (Kassin et al., 2012). Unplanned readmission within 30 days due to postoperative complications cost the US Medicare program about USD\$17 billion per year (Jencks et al., 2009). For surgical patients, insufficient discharge education contributes to poor outcomes including wound and gastrointestinal complications, pulmonary embolism, and deep vein thrombosis resulting in increased morbidity, return visits to the emergency department and unplanned hospital re-admission (Jack et al., 2009; Pieper et al., 2006; Sivarajan \& Ganesan, 2012).

With the increasing provision of financial incentives and 'enhanced recovery' care pathways, greater emphasis has been placed on shorter hospitalisations. Surgical patients are now often discharged once they can mobilise (Carter et al., 2016; Loubani et al., 2000). Depending on the communication skills of the health professionals imparting the instructions, discharge education may be insufficiently conveyed by health professionals facilitating the discharge process (Henderson \& Zernike, 2001). Additionally, discharge education delivered to patients may be poorly understood when education provided is standardised and not tailored to meet the needs of the individual patient (Eldh et al., 2006; McMurray et al., 2007). These factors impose a burden on patients who may be ill prepared to manage post-operative complications after discharge.

\subsection{Previous reviews}

Recent reviews have examined discharge education delivered to surgical patients preoperatively (Fredericks et al., 2010; Louw et al., 2013; Ronco et al., 2012; Veronovici, 2014). Ronco et al. (2012) systematic review focussed on the timing and dose of the discharge education delivered to patients with all types of surgical procedures. They identified education provided to surgical patients preoperatively was delivered several months before and after surgery, and the education sessions were repeated more than once. Other reviews have focused on various patient outcomes. For instance, Veronovici (2014) review of preoperative discharge education delivered to cardiovascular surgery patients found that discharge education led to positive outcomes such as decreased anxiety and depression, with fewer physical complications after surgery, however, these findings were inconsistent. Louw et al. (2013) systematic review found that preoperative education delivered to joint arthroplasty patients did not lead to a reduction in pain postoperatively. 
Other reviews have focused on the ways in which postoperative discharge education programs/resources have been adapted to meet the needs of specific patient groups when education has been provided postoperatively. Frederick and colleagues (2010) review on postoperative education suggests that education needs to be tailored to reflect the learning needs of individuals, as 'standardised education' refers to learning resources created for general distribution. A more recent review by Frederick and Yau (2013) of postoperative education for patients undergoing coronary artery bypass grafting found significant improvement in information retention and self-managements skills in patients who received individualised education compared to those who received standardised education. This review also found no differences in effect when education was delivered preoperatively or postoperatively.

Overall, these reviews concluded that education should be administered as soon as the patient has been informed about the surgery and throughout the hospitalisation period (Fredericks et al., 2010; Louw et al., 2013; Ronco et al., 2012; Veronovici, 2014). However, the overall findings were inconclusive relative to the timing and dose of discharge education provided during either the preoperative or postoperative periods. The majority of the reviews identified focused on specialties such cardiac and orthopaedic surgery rather general surgery. As such, a mixed studies review was undertaken to identify the types, timing and dosage of discharge education provided and by whom to surgical patients in their management of recovery after surgery.

\section{Methods}

\subsection{Design}

A systematic mixed studies review guided by Pluye and Hong's framework (Pluye \& Hong, 2014) was undertaken to describe, critically appraise and synthesise the types of discharge education delivered to general surgical patients. This method allow qualitative, quantitative and/or mixed methods studies to be included and synthesised to obtain a holistic understanding of a given problem (Pluye \& Hong, 2014). To ensure the process for this review is rigorous, the seven stages of conducting a mixed studies review outlined by the mixed studies review guidelines were utilised (Pluye \& Hong, 2014). Based on a priori criteria, this review has been registered with PROSPERO (CRD42018086946). We used the Preferred Reporting Items for Systematic Reviews and Meta-Analysis (PRISMA) statement (Moher et al., 2009) to report review findings. 


\section{Stage 1: Formulate a review question}

The aim of this mixed studies review was to identify the discharge education provided to general surgical patients. Subsumed in this aim, the following research questions guided the search strategy:

1. Who delivers the discharge education provided to general surgical patients?

2. What is the content of the discharge education provided to general surgical patients?

3. How is the discharge education delivered to general surgical patients?

4. When is the discharge education delivered to general surgical patients?

The following conceptual definitions were used to inform the eligibility criteria and literature search strategies.

General surgery: This surgical speciality focuses on the alimentary tract, the abdomen and its contents, breast skin and soft tissue, and the endocrine system (The American Board of Surgery, 2017). For this review, sub-specialties such as gastrointestinal (digestive system procedure), hepatobiliary surgery, appendectomy, pancreatic surgery and colorectal surgery performed laparoscopically or laparotomy involving penetration into the peritoneal cavity were included in the review.

Discharge education: Defined as the delivery of planned education provided by health care providers (i.e. doctors or nurses) for patients to facilitate their knowledge base for recovery at home after discharge from hospital (Lin et al., 2012; Taylor \& Cameron, 2000). The goal of this education is to ensure patients are equipped with the appropriate knowledge for selfmanagement of their recovery after leaving hospital, reducing the occurrence of postoperative complications and unexpected return to hospital (Kassin et al., 2012). Different media and formats of discharge education (i.e. face to face, written or audio-visual) were included in the mixed studies review.

\section{Stage 2: Define eligibility criteria}

Qualitative, quantitative and mixed methods published studies were included to gain a comprehensive understanding of discharge education provided to general surgical patients. Inclusion and exclusion criteria (Table 1) were used to guide study selection for this review. 
Table 1 Inclusion and Exclusion Criteria

\begin{tabular}{|c|c|}
\hline Inclusion Criterion & Justification \\
\hline $\begin{array}{l}\text { General surgical patients } \\
\text { over } 16 \text { years of age }\end{array}$ & $\begin{array}{l}\text { This includes adolescents over this age who are deemed } \\
\text { competent to consent for surgery as defined by the } \\
\text { principles established by Gillick's competence. (Griffith, } \\
\text { 2016) }\end{array}$ \\
\hline English language & $\begin{array}{l}\text { The most accessible and widely read journals are published } \\
\text { in the English language. }\end{array}$ \\
\hline Time period 2008-2017 & $\begin{array}{l}\text { This period reflects advances in surgical technologies / } \\
\text { methods (i.e., laparoscopic- assisted robotic surgery) with } \\
\text { such advances likely influencing the type of discharge } \\
\text { education provided. }\end{array}$ \\
\hline Discharge education & $\begin{array}{l}\text { No limits were set for the content and delivery methods } \\
\text { used in discharge education as one of the aims of this } \\
\text { review was to identify the content and delivery methods of } \\
\text { the education. }\end{array}$ \\
\hline Primary research & $\begin{array}{l}\text { Reports based on empirical data using either qualitative, } \\
\text { qualitative or mixed methods. }\end{array}$ \\
\hline Exclusion Criterion & $\begin{array}{r}\text { Justification } \\
\end{array}$ \\
\hline $\begin{array}{l}\text { Surgical procedures for } \\
\text { weight reduction (i.e., } \\
\text { bariatric surgery) and } \\
\text { malignant conditions. }\end{array}$ & $\begin{array}{l}\text { These procedures were excluded due to the differences in } \\
\text { the population of interest. Discharge education provided } \\
\text { may be different due to the additional treatment regimens } \\
\text { involved (Lithner et al., 2006). Studies were included if } \\
\text { subgroup data of non-malignant participants was reported } \\
\text { separately and therefore could be extracted. }\end{array}$ \\
\hline $\begin{array}{l}\text { Multifaceted care bundles } \\
\text { such as fast track surgery or } \\
\text { in enhanced recovery after } \\
\text { surgery treatment program. }\end{array}$ & $\begin{array}{l}\text { As bundled interventions are used in enhanced recovery } \\
\text { after surgery protocols, it is difficult to determine what } \\
\text { component of the intervention led to the reported } \\
\text { improvement. }\end{array}$ \\
\hline $\begin{array}{l}\text { Admission under } 24 \text { hours } \\
\text { (i.e., ambulatory surgery) }\end{array}$ & $\begin{array}{l}\text { Patients admitted for shorter periods of time were excluded } \\
\text { as discharge instructions provided might be different. }\end{array}$ \\
\hline $\begin{array}{l}\text { Grey literature sources (e.g., } \\
\text { conference proceedings) } \\
\text { except for doctoral theses }\end{array}$ & $\begin{array}{l}\text { These sources have not been subjected to a high quality, } \\
\text { peer review process. }\end{array}$ \\
\hline $\begin{array}{l}\text { Reports that describe quality } \\
\text { improvement initiatives } \\
\text { without a research } \\
\text { methodology and/or } \\
\text { theoretical approach. }\end{array}$ & $\begin{array}{l}\text { Quality improvement initiatives in the absence of a } \\
\text { research methodology and/or theoretical approach lack } \\
\text { sufficient level of evidence. }\end{array}$ \\
\hline
\end{tabular}




\section{Stage 3: Apply an extensive search strategy}

A two-step systematic search strategy was conducted to enhance the quality of the review from December 2017 to January 2018. The first step involved the computerised database search. To undertake this search, the SPIDER tool (Sample, Phenomenon of interest, Design, Evaluation, Research type) was used (Cooke et al., 2012). The SPIDER search tool can be used effectively in the retrieval of quantitative, qualitative and mixed methods research (Cooke et al., 2012). Using three elements of the tool; sample, phenomenon of interest and research types, a detailed database search strategy was developed with the assistance of a specialist health librarian. The sample was identified as patients that had undergone general surgery. Discharge education was the phenomenon of interest and descriptive terms used synonymously, were searched. Consistent with a mixed studies review, qualitative, quantitative and mixed method studies were included as research types in this review. The database search strategy was conducted using the four largest medical and nursing research databases (EBSCO CINAHL Plus, EBSCO MEDLINE, Ovid EMBASE and COCHRANE Library). Search terms included subject headings and keywords terms related to a same concept and were combined using Boolean operators AND, OR and NOT. Criteria such as language, publication type and age group were used to limit the search to reduce the number of irrelevant records. Detailed search strategies are presented in Appendix 1. The second step of the search included hand-searching reference lists of journals articles included in the review for studies meeting inclusion criteria as computerised database searches only reveal approximately $50 \%$ of relevant studies (Hopewell et al., 2007).

\section{Stage 4 and 5: Identify potential relevant studies and select relevant studies}

Empirical studies on discharge education for general surgery patients were identified (See figure 1). Records retrieved during database searching were exported to the reference software manager, Endnote $\mathrm{x} 9$ and were later exported to the program Rayyan (http://rayyan.qcri.org/). Rayyan is an online tool designed specifically for the initial screening and systematic coding of studies. Elimination of duplicated articles was performed 
prior to screening. Two members of the research team independently reviewed the titles and abstracts based on predetermined eligibility criteria. Full text articles were downloaded and screened for articles without sufficient detail to determine eligibility. Once full texts were obtained for articles meeting eligible criteria, they were reviewed independently by the same 2 members of the research team to identify studies for inclusion. Regular discussions were held among the researchers and disagreements were resolved through discussion. A third person was assigned to adjudicate over discrepancies between the two reviewers although this was not necessary.

\section{Stage 6: Appraise the quality of included studies}

The Mixed Methods Appraisal Tools (MMAT) (Pluye et al., 2011) was used to calculate the quality scores of the included studies. Compared to other tools, the MMAT is designed specifically for appraising the methodological quality of quantitative, qualitative and mixed methods studies included in a mixed studies review and has demonstrated established validity and reliability (Pluye et al., 2009; Pluye \& Hong, 2014). Studies were not excluded based on their quality appraisal as the intention was to map the overall quality of studies in this field of research and provide further insights in relation to the different aspects of discharge education provided to general surgical patients. The articles were assessed against the appropriate MMAT criteria based on the study methodology which provided an overall quality score. Scores vary from $0 \%$ to $25 \%(*)$ representing one criterion to $100 \%(* * * *)$ when all criteria are met (Pluye et al., 2009). To increase the rigour of quality assessment, a member of the research team and a research assistant independently conducted the appraisal process and met to discuss their MMAT scores and the overall quality of the studies. Interrater agreement between both reviewers was calculated using Cohen's Kappa statistic (Kappa $=1 ; \mathrm{p}<0.001)$.

\section{Stage 7: Thematic synthesis}

Using the framework of thematic synthesis by Thomas and Harden (2008), thematic synthesis was conducted in three stages. The lead author immersed herself in the data by reading and re-reading the 'results' or 'findings' section of the each article. Next, data were coded line by line using words to identify similar concepts across studies. Microsoft Excel 2010 was used in the data management of the line by line coding of included studies. To produce a synthesis that is close to the findings of the included studies, the inductive codes were compared and 
contrasted and grouped together based on their similarities and then organised into subcategories, and higher order categories to provide descriptive themes. Finally, analytical themes began emerging by returning to the textual data to identify themes. Emerging themes were discussed between two review authors and changes were made. The entire team then met to discuss the emerging themes across the studies until consensus was reached.
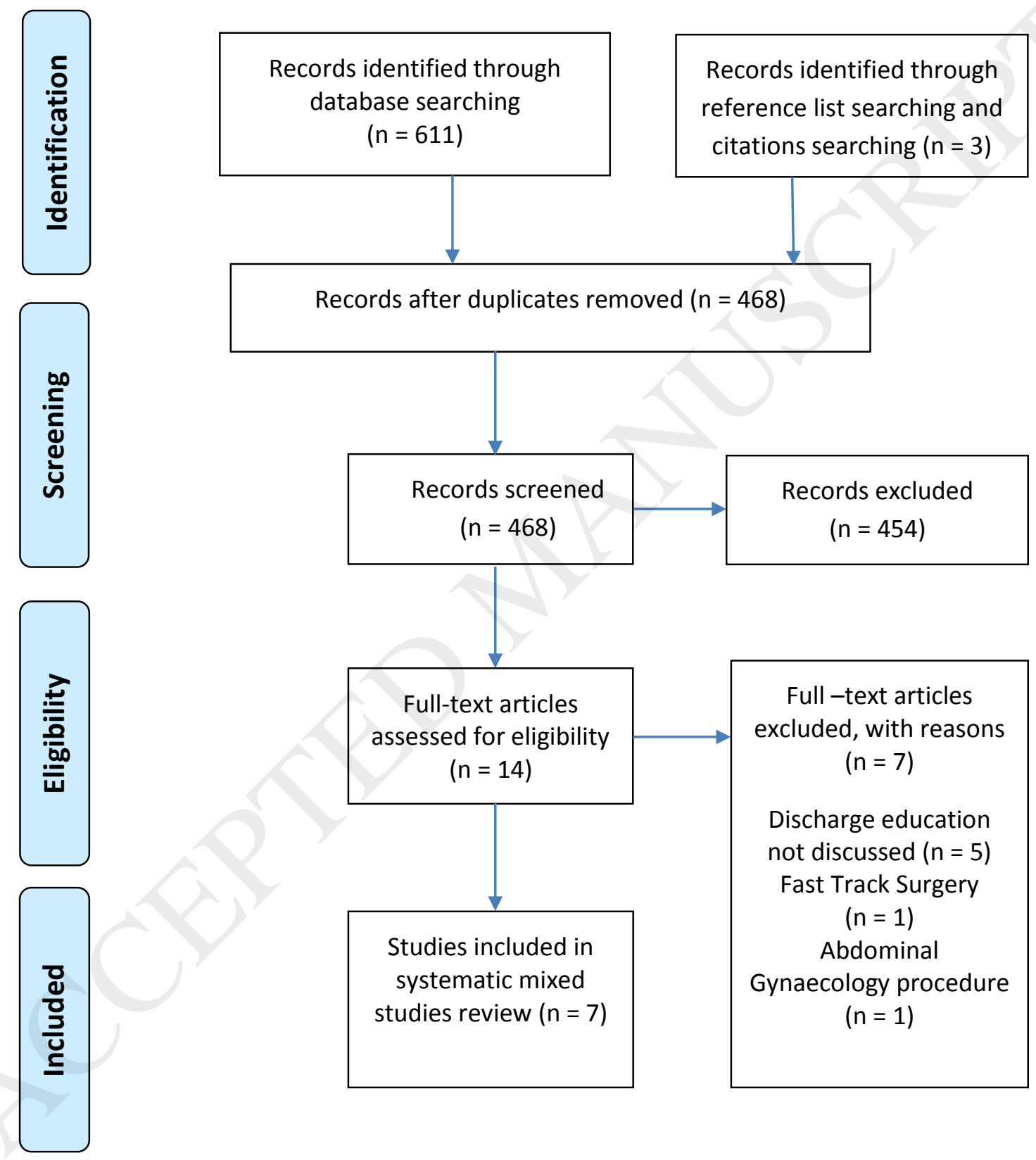

Fig. 1. PRISMA flow chart for search strategy 
Table 2: Overview of studies

\begin{tabular}{|c|c|c|c|c|c|c|c|c|c|}
\hline $\begin{array}{l}\text { Author, } \\
\text { year and } \\
\text { country }\end{array}$ & Approach & Context & Intervention & Findings & $\begin{array}{l}\text { Who -delivered } \\
\text { discharge education }\end{array}$ & $\begin{array}{l}\text { What- discharge } \\
\text { education delivered }\end{array}$ & $\begin{array}{l}\text { When- discharge } \\
\text { education delivered }\end{array}$ & $\begin{array}{l}\text { How - discharge } \\
\text { education delivered }\end{array}$ & MMAT \\
\hline $\begin{array}{l}\text { Sayin } \\
\text { and } \\
\text { Aksoy } \\
(2012) \\
\text { Turkey }\end{array}$ & $\begin{array}{l}\text { Aim: To establish } \\
\text { information } \\
\text { needs of } \\
\text { perioperative } \\
\text { patients and their } \\
\text { family members, } \\
\text { and the role } \\
\text { nurses play in } \\
\text { providing this } \\
\text { information. } \\
\text { Design: Cross- } \\
\text { sectional } \\
\text { descriptive study } \\
\text { Data collection: } \\
\text { Survey } \\
\text { - } 1 \text { for } \\
\text { patients, } \\
1 \text { for family } \\
\text { members } \\
1 \text { for nurses) }\end{array}$ & $\begin{array}{l}\text { Setting: Liver- } \\
\text { biliary tract, } \\
\text { breast, } \\
\text { endocrine, } \\
\text { peripheral } \\
\text { vascular, } \\
\text { colon rectum, } \\
\text { and general } \\
\text { surgical } \\
\text { department of } \\
\text { a hospital } \\
\text { Sample } \\
\text { Patients } \\
\text { (n=197) } \\
\text { Family } \\
\text { members/ } \\
\text { dyads } \\
\text { (n=197) } \\
\text { Nurses (n=30) }\end{array}$ & Nil & $\begin{array}{l}\text { - Inadequate information given } \\
\text { to patients ( } \mathrm{n}=137 ; 69.5 \%) \\
\text { and family members }(\mathrm{n}=132 ; \\
67 \%) \text {. } \\
\text { - Patients ( } \mathrm{n}=110 ; 55.8 \% \text { ) and } \\
\text { family members }(\mathrm{n}=120 ; \\
60.9 \% \text { ) prefer information } \\
\text { without medical jargon and in } \\
\text { understandable language. } \\
\text { - Patients (n=156; 79.2\%) and } \\
\text { family members (n=155; } \\
78.7 \% \text { ) prefer education } \\
\text { delivered with pictures and in } \\
\text { an environment where they } \\
\text { can discuss the information } \\
\text { given. } \\
\text { - Patients (n=197; } 100 \% \text { ) and } \\
\text { family members ( } \mathrm{n}=197 ; \\
100 \% \text { ) prefer physicians to } \\
\text { deliver information as } \\
\text { compared to nurses. } \\
\text { - Patients and family prefer } \\
\text { additional information about: } \\
\checkmark \quad \text { Changes in activities } \\
\quad \text { of daily living } \\
\checkmark \quad \text { Home care } \\
\checkmark \quad \text { Diet/medication }\end{array}$ & $\begin{array}{l}\text { Delivered by } \\
\text { physicians and } \\
\text { nurses to patients } \\
\text { and family } \\
\text { members. }\end{array}$ & $\begin{array}{l}\text { - Possible } \\
\text { complications } \\
\text { postoperatively } \\
\text { - Wound care } \\
\text { - Follow-up care } \\
\text { after discharge } \\
\text { - Time and form of } \\
\text { nutrition and how } \\
\text { it relates to } \\
\text { activity } \\
\text { - Date and time of } \\
\text { discharge } \\
\text { - Pathology results } \\
\text { - Postoperative } \\
\text { suture removal } \\
\text { - Medication } \\
\text { treatment } \\
\text { continued at home }\end{array}$ & Preoperatively & $\begin{array}{l}\text { - Short oral } \\
\text { explanation } \\
\text { - Brochures } \\
\text { - Discussion(i.e. } \\
\text { questions and } \\
\text { answers) } \\
\text { Visual material (i.e. } \\
\text { pictures, models) }\end{array}$ & **** \\
\hline
\end{tabular}




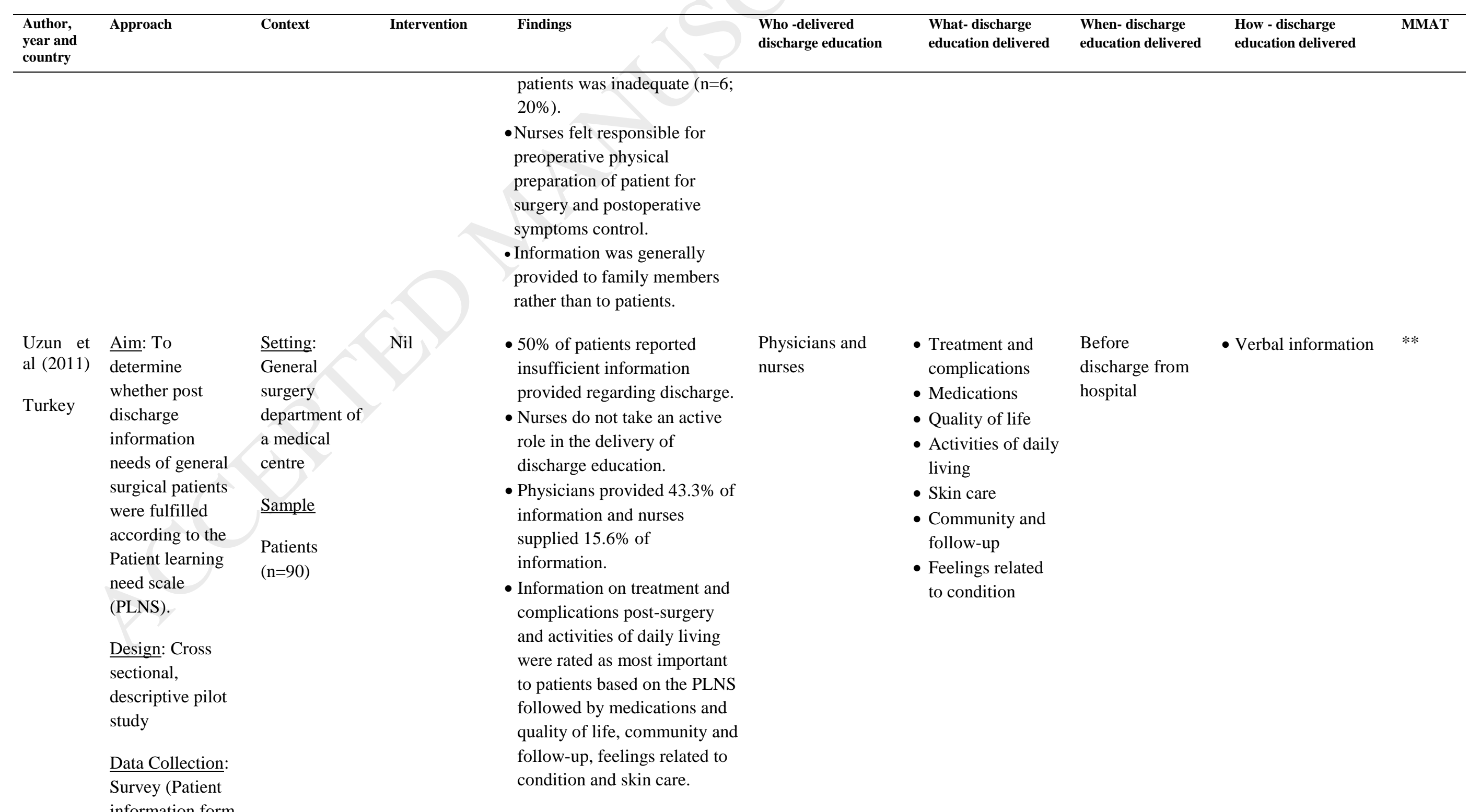




\begin{tabular}{|c|c|c|c|c|c|c|c|c|c|}
\hline $\begin{array}{l}\text { Author, } \\
\text { year and } \\
\text { country }\end{array}$ & Approach & Context & Intervention & Findings & $\begin{array}{l}\text { Who -delivered } \\
\text { discharge education }\end{array}$ & $\begin{array}{l}\text { What- discharge } \\
\text { education delivered }\end{array}$ & $\begin{array}{l}\text { When- discharge } \\
\text { education delivered }\end{array}$ & $\begin{array}{l}\text { How - discharge } \\
\text { education delivered }\end{array}$ & MMAT \\
\hline & $\begin{array}{l}\text { and Turkish } \\
\text { version of PLNS }\end{array}$ & & & & & & & & \\
\hline $\begin{array}{l}\text { Williams } \\
\text { (2008) } \\
\text { Canada }\end{array}$ & $\begin{array}{l}\text { Aim: To } \\
\text { determine } \\
\text { whether the } \\
\text { information that } \\
\text { people received } \\
\text { following general } \\
\text { abdominal } \\
\text { surgery was } \\
\text { adequate for them } \\
\text { to be able to care } \\
\text { for themselves at } \\
\text { home. } \\
\text { Design: } \\
\text { Descriptive study } \\
\text { Data Collection: } \\
\text { Self-reported } \\
\text { questionnaire (on } \\
\text { discharge) and } \\
\text { phone interview } \\
\text { survey } \\
\text { (conducted } 3 \\
\text { weeks after } \\
\text { discharge) and } \\
\text { chart audit. }\end{array}$ & $\begin{array}{l}\text { Setting: } \\
\begin{array}{l}\text { Surgical ward } \\
\text { at a large } \\
\text { tertiary care } \\
\text { hospital }\end{array} \\
\underline{\text { Sample }} \\
\text { Patients } \\
\text { undergoing } \\
\text { general } \\
\text { abdominal } \\
\text { surgery } \\
(\mathrm{n}=109)\end{array}$ & Nil & $\begin{array}{l}\text { Prior to discharge } \\
\text { - } 84 \% \text { of patients received } \\
\text { information on how to } \\
\text { manage their pain and } 83 \% \text { of } \\
\text { patients received information } \\
\text { about how to care for their } \\
\text { wounds prior to discharge. } \\
\text { - } 74 \% \text { of patients received } \\
\text { information on the activities } \\
\text { they could do. } \\
\text { 66\% of patients received } \\
\text { information on what } \\
\text { complications to watch for. } \\
\text { - } 46 \% \text { of patients received } \\
\text { printed information to take } \\
\text { home. } \\
\text { - 58\% of patients were satisfied } \\
\text { with the information provided } \\
\text { at point of discharge. } \\
\text { Information 1-3 weeks post } \\
\text { discharge } \\
\text { Patients felt informed about } \\
\text { pain management, wound } \\
\text { care, activities, nutrition and } \\
\text { complications on discharge } \\
\text { were still likely to believe it }\end{array}$ & Nurses & $\begin{array}{l}\text { - Pain management } \\
\text { information such } \\
\text { as prescription } \\
\text { for analgesia } \\
\text { - Wound care } \\
\text { information such } \\
\text { as when to } \\
\text { shower and to } \\
\text { clean the incision } \\
\text { were available in } \\
\text { print and provided } \\
\text { to patients. } \\
\text { - Activities after } \\
\text { surgery such as } \\
\text { lifting, driving. } \\
\text { - Nutrition } \\
\text { regarding food to } \\
\text { eat and avoid. } \\
\text { - Post-operative } \\
\text { complications and } \\
\text { health care } \\
\text { facility to access } \\
\text { should } \\
\text { complications } \\
\text { arise. } \\
\text { - Follow up } \\
\text { appointment from } \\
\text { home care nurse }\end{array}$ & $\begin{array}{l}\text { Delivered prior } \\
\text { to discharge }\end{array}$ & $\begin{array}{l}\text { - Verbal instructions } \\
\text { delivered prior to } \\
\text { discharge. } \\
\text { - Printed information } \\
\text { given at } \\
\text { preadmission } \\
\text { clinic. }\end{array}$ & $* * * *$ \\
\hline
\end{tabular}




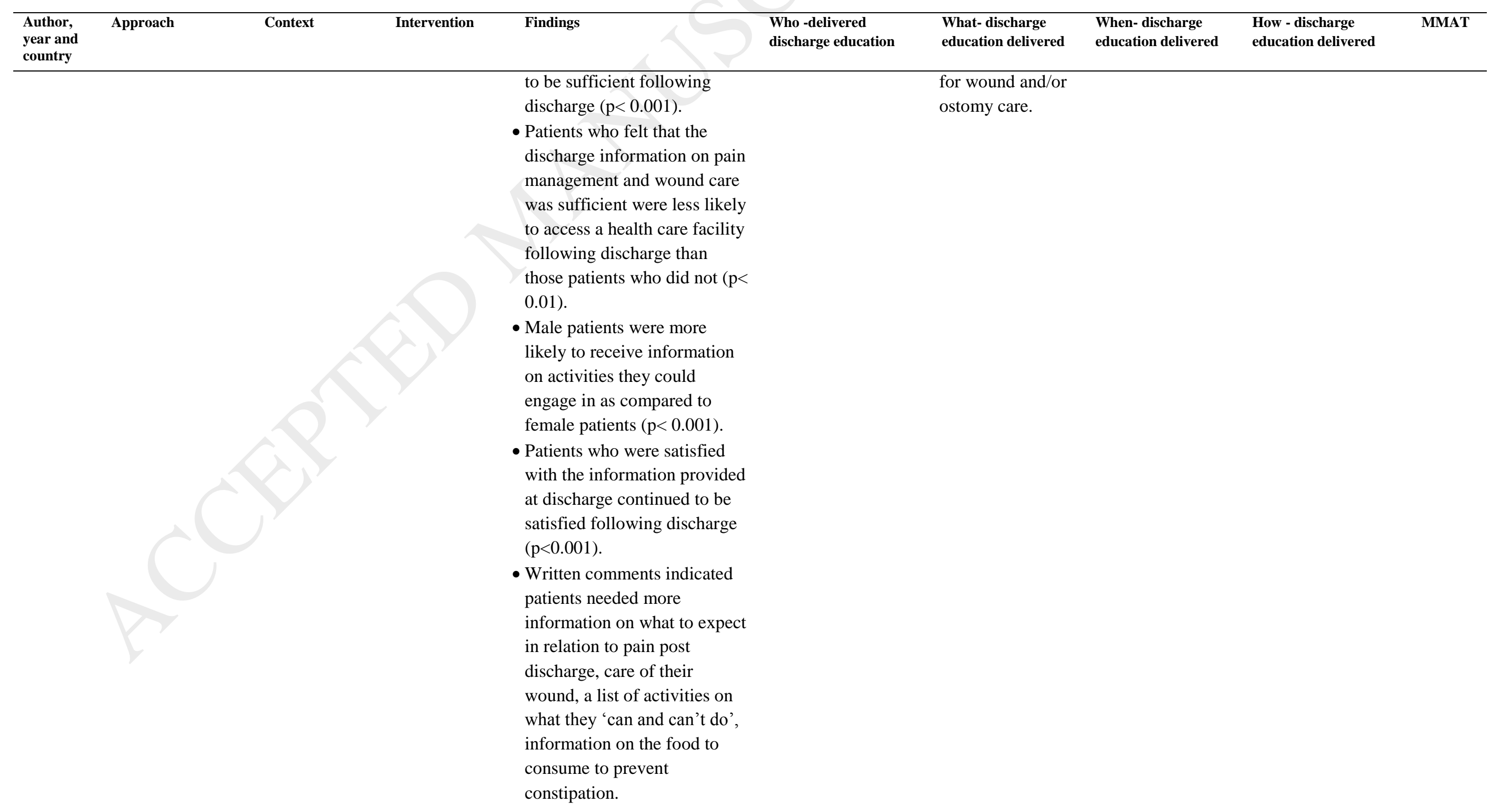




\begin{tabular}{|c|c|c|c|c|c|c|c|c|c|}
\hline $\begin{array}{l}\text { Author, } \\
\text { year and } \\
\text { country }\end{array}$ & Approach & Context & Intervention & Findings & $\begin{array}{l}\text { Who -delivered } \\
\text { discharge education }\end{array}$ & $\begin{array}{l}\text { What- discharge } \\
\text { education delivered }\end{array}$ & $\begin{array}{l}\text { When- discharge } \\
\text { education delivered }\end{array}$ & $\begin{array}{l}\text { How - discharge } \\
\text { education delivered }\end{array}$ & MMAT \\
\hline & & & & $\begin{array}{l}\text { - Patients who encountered } \\
\text { problems related to wound } \\
\text { care attributed it to the lack of } \\
\text { information provided. (i.e } \\
\text { cleaning of wound when the } \\
\text { dressing came off). } \\
\text { - Patients indicated they would } \\
\text { like to know how to tell if } \\
\text { their wounds were infected } \\
\text { and how to care for their } \\
\text { drains. } \\
\text { - Some patients indicated they } \\
\text { were unsure of how to tell if } \\
\text { something were 'abnormal' } \\
\text { postoperatively. } \\
\text { - Printed and verbal } \\
\text { instructions provided were } \\
\text { inconsistent and } 46 \% \text { of } \\
\text { patents received printed } \\
\text { information to take home with } \\
\text { them when they attended the } \\
\text { preadmission clinic several } \\
\text { weeks before their admission. } \\
\text { - Patients who received } \\
\text { printed information revealed } \\
\text { they refer to it an average of } 4 \\
\text { times following discharge. } \\
\text { - Possible knowledge deficit for } \\
\text { patients admitted for } \\
\text { emergency surgery due to the } \\
\text { lack of written information }\end{array}$ & & & & & \\
\hline
\end{tabular}




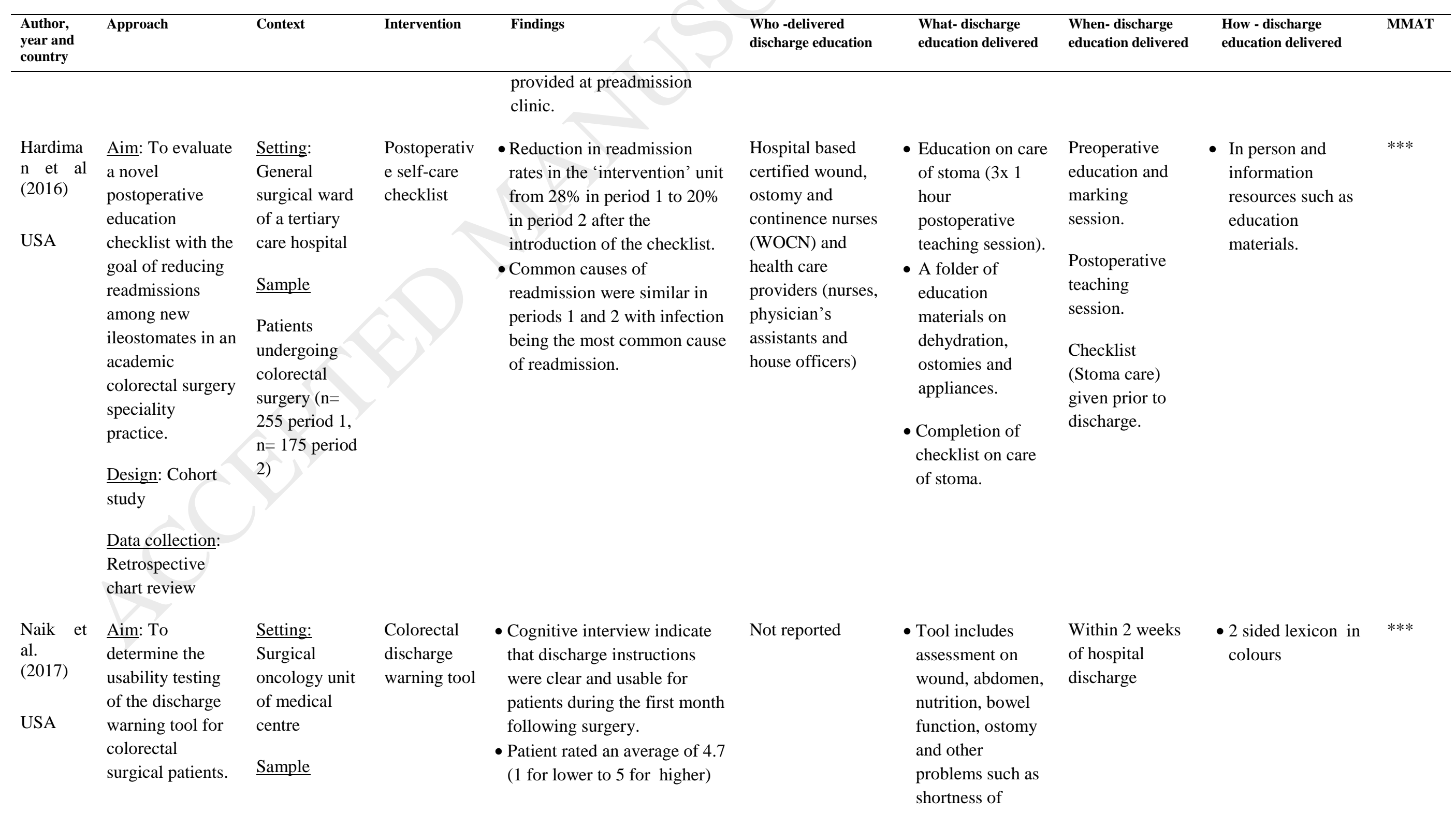




\begin{tabular}{|c|c|c|c|c|c|c|c|c|c|}
\hline $\begin{array}{l}\text { Author, } \\
\text { year and } \\
\text { country }\end{array}$ & Approach & Context & Intervention & 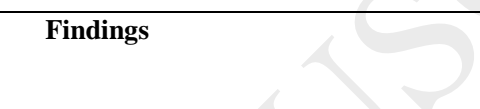 & $\begin{array}{l}\text { Who -delivered } \\
\text { discharge education }\end{array}$ & $\begin{array}{l}\text { What- discharge } \\
\text { education delivered }\end{array}$ & $\begin{array}{l}\text { When- discharge } \\
\text { education delivered }\end{array}$ & $\begin{array}{l}\text { How - discharge } \\
\text { education delivered }\end{array}$ & $\overline{\text { MMAT }}$ \\
\hline & $\begin{array}{l}\text { Design: Heuristic } \\
\text { evaluation using } \\
\text { Delphi panel and } \\
\text { interviews } \\
\text { Phase 1: literacy } \\
\text { evaluation of } \\
\text { discharge } \\
\text { warnings } \\
\text { prototype } \\
\text { Phase 2: heuristic } \\
\text { evaluation of } \\
\text { discharge } \\
\text { warning lexicon } \\
\text { Data collection: } \\
\text { semi structured } \\
\text { interviews via } \\
\text { telephone } \\
\text { regarding } \\
\text { usability of } \\
\text { discharge } \\
\text { warning tool }\end{array}$ & $\begin{array}{l}\text { Patients } \\
\text { undergoing } \\
\text { colorectal } \\
\text { surgery }(\mathrm{n}=7)\end{array}$ & & $\begin{array}{l}\text { for clarity of information on } \\
\text { the discharge warning page. } \\
\text { - Sense making lexicon was } \\
\text { easily understood as 'warning } \\
\text { sign' that provides clear } \\
\text { instructions to patients on } \\
\text { when to act. }\end{array}$ & & $\begin{array}{l}\text { breath and chest } \\
\text { pain. } \\
\text { - Everyday care } \\
\text { instructions } \\
\text { including } \\
\text { activities such as } \\
\text { deep breathing } \\
\text { and follow up } \\
\text { appointments. }\end{array}$ & & & \\
\hline $\begin{array}{l}\text { Powell et } \\
\text { al (2009) } \\
\text { United } \\
\text { Kingdo } \\
\mathrm{m}\end{array}$ & $\begin{array}{l}\text { Aim: To } \\
\text { understand the } \\
\text { usefulness of } \\
\text { information and } \\
\text { instructions from } \\
\text { patients' } \\
\text { perspectives }\end{array}$ & $\begin{array}{l}\text { Setting: } \\
\text { University, } \\
\text { hospital, } \\
\text { participant's } \\
\text { home and } \\
\text { workplace } \\
\text { Sample }\end{array}$ & Nil & $\begin{array}{l}\text { - Past experience of others (who } \\
\text { had similar procedure) had an } \\
\text { influence on their } \\
\text { management of surgical } \\
\text { experience. } \\
\text { - Informal social networks, i.e. } \\
\text { internet used as an information } \\
\text { source to find out about the }\end{array}$ & $\begin{array}{l}\text { Health care } \\
\text { professionals } \\
\text { (HCP) }\end{array}$ & $\begin{array}{l}\text { - Information } \\
\text { regarding } \\
\text { incisional site and } \\
\text { management of } \\
\text { postoperative } \\
\text { symptoms such as } \\
\text { pain, bruising, }\end{array}$ & $\begin{array}{l}\text { Pre-operative } \\
\text { stage and } \\
\text { follow-up after } \\
\text { surgery }\end{array}$ & $\begin{array}{l}\text { - Face to face } \\
\text { consultation }\end{array}$ & $* * * *$ \\
\hline
\end{tabular}




\begin{tabular}{|c|c|c|c|c|c|c|c|c|c|}
\hline $\begin{array}{l}\text { Author, } \\
\text { year and } \\
\text { country }\end{array}$ & Approach & Context & Intervention & 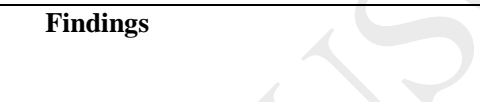 & $\begin{array}{l}\text { Who -delivered } \\
\text { discharge education }\end{array}$ & $\begin{array}{l}\text { What- discharge } \\
\text { education delivered }\end{array}$ & $\begin{array}{l}\text { When- discharge } \\
\text { education delivered }\end{array}$ & $\begin{array}{l}\text { How - discharge } \\
\text { education delivered }\end{array}$ & MMAT \\
\hline & $\begin{array}{l}\text { throughout the } \\
\text { surgical pathway. } \\
\text { Design: } \\
\text { Interpretive } \\
\text { phenomenology } \\
\text { Data Collection: } \\
\text { In depth, semi- } \\
\text { structured } \\
\text { interviews at } 3 \\
\text { time points } \\
\checkmark \text { Time point } \\
1-2 \text { weeks } \\
\text { before } \\
\text { surgery; } \\
\checkmark \text { time point } 2 \\
\text { and } 3-2 \\
\text { weeks and } 4 \\
\text { months post- } \\
\text { surgery }\end{array}$ & $\begin{array}{l}\text { Patients } \\
\text { undergoing } \\
\text { inguinal hernia } \\
\text { procedures } \\
(\mathrm{n}=7)\end{array}$ & & $\begin{array}{l}\text { surgery and to manage their } \\
\text { symptoms after surgery on top } \\
\text { of the information provided by } \\
\text { HCPs. } \\
\text { - Preoperative interviews from } \\
\text { HCPs, a key source of } \\
\text { information for post-surgery. } \\
\text { - Desire for instructions on } \\
\text { returning to activities and } \\
\text { post-operative symptoms. } \\
\text { - Conflicting information from } \\
\text { surgeon and GP regarding } \\
\text { return to work. When advice } \\
\text { clashed with the need to earn } \\
\text { living, compromises were } \\
\text { made. }\end{array}$ & & $\begin{array}{l}\text { swelling and } \\
\text { numbness. } \\
\text { - Post discharge } \\
\text { analgesic use to } \\
\text { help with } \\
\text { incisional pain. } \\
\text { - Advice and } \\
\text { behavioural } \\
\text { instructions on } \\
\text { resuming normal } \\
\text { activities and } \\
\text { return to work. }\end{array}$ & & & \\
\hline $\begin{array}{l}\text { Horstma } \\
\mathrm{n} \text { et al } \\
(2017) \\
\text { USA }\end{array}$ & $\begin{array}{l}\text { Aim: To examine } \\
\text { the role of } \\
\text { discharge } \\
\text { instructions in } \\
\text { post discharge } \\
\text { care for patients } \\
\text { undergoing } \\
\text { colorectal surgery } \\
\text { and report themes }\end{array}$ & $\begin{array}{l}\text { Setting: Single } \\
\text { veteran affair } \\
\text { hospital } \\
\text { Patients } \\
\text { undergoing } \\
\text { colorectal } \\
\text { surgery }(\mathrm{n}=12)\end{array}$ & $\begin{array}{l}\text { Project Re- } \\
\text { Engineered } \\
\text { Discharge } \\
\text { Intervention }\end{array}$ & $\begin{array}{l}\text { - Discharge instructions } \\
\text { provided patients with a sense } \\
\text { of security as it removes } \\
\text { doubt or uncertainty after } \\
\text { discharge. } \\
\text { - Discharge instructions serve } \\
\text { as a reminder of verbal } \\
\text { instructions provided in } \\
\text { hospital. }\end{array}$ & $\begin{array}{l}\text { Unit nurse review } \\
\text { discharge } \\
\text { instructions at the } \\
\text { general surgery } \\
\text { inpatient unit. }\end{array}$ & $\begin{array}{l}\text { - The AHCP } \\
\text { contains patient } \\
\text { centric } \\
\text { medication list, } \\
\text { medication } \\
\text { instructions, } \\
\text { directions for how } \\
\text { to refill } \\
\text { medications, }\end{array}$ & $\begin{array}{l}\text { At discharge } \\
\text { The AHCP is a } \\
\text { tool to be used } \\
\text { post discharge. }\end{array}$ & - Written and verbal & $* * *$ \\
\hline
\end{tabular}




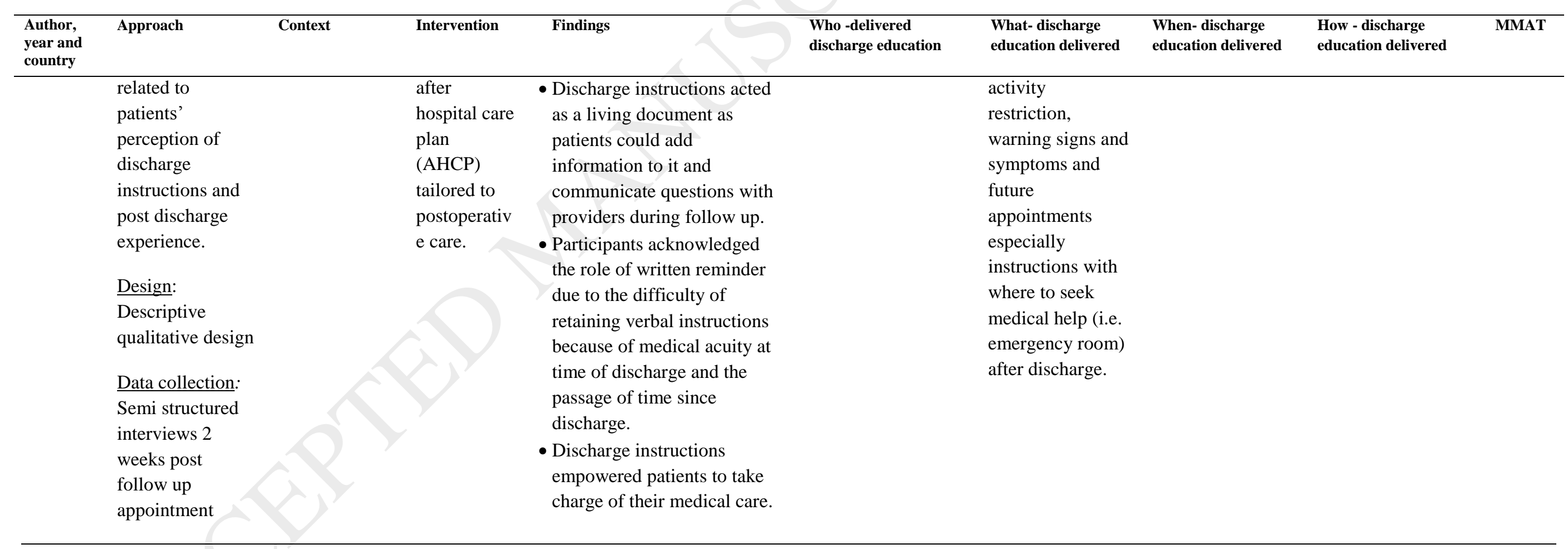

Abbreviations: Patient learning need scale (PLNS); wound, ostomy and continence nurses (WOCN); $\mathrm{HCP}=\mathrm{Health}$ care professionals; $\mathrm{AHCP}=$ after hospital care plan 


\subsection{Rigour}

In undertaking this mixed studies review, we followed a systematic review process that is widely accepted (Pluye \& Hong, 2014). The accuracy of the data was ensured by conducting a comprehensive systematic search strategy, coupled with detailed documentation of search decisions. Credibility of data interpretation was maintained through memo interpretations to provide an audit trail for decisions, and having regular team meetings to discuss emergent findings. Interpretive validity to ensure representation of the primary researchers' viewpoints was enacted by having two reviewers independently extract data without interpretation, and considering quality appraisal to ensure conclusions were not overstated (Thomas \& Harden, 2008). Transferability of the synthesised findings was demonstrated through including data extraction tables, including context, allowing readers to judge the usefulness of the findings to their clinical settings (Thomas \& Harden, 2008).

\section{Results}

\subsection{Included studies}

A total of 468 records were identified and their titles and abstracts screened based on predetermined eligibility criteria with 454 studies excluded. Studies were excluded if they did not meet the inclusion criteria (e.g. did not discuss discharge education, patients undergoing cancer treatment). Seven articles were included in the mixed studies review as shown in the PRISMA flow diagram (Table 1). Of the included studies, four were quantitative studies (two cross sectional descriptive studies (Sayin \& Aksoy, 2012; Uzun et al., 2011), one descriptive study (Williams, 2008) and one non randomised study (Hardiman et al., 2016) using surveys (Sayin \& Aksoy, 2012; Uzun et al., 2011) and chart review (Hardiman et al., 2016). In qualitative studies, a broad range of methods were used, including focus groups and/or individual interviews (Horstman et al., 2017; Naik et al., 2017; Powell et al., 2009) and Delphi process (Naik et al., 2017). A descriptive summary of the studies with their quality scores is presented in Table 2. Participants included in the review were patients undergoing general surgery ( $\mathrm{n}=287$ ) (Sayin \& Aksoy, 2012; Uzun et al., 2011), abdominal surgery $(n=109)$, (Williams, 2008) colorectal surgery $(n=449)$ (Hardiman et al., 2016; Horstman et al., 2017; Naik et al., 2017) and inguinal hernia surgery (n=12) (Powell et al., 2009). Six of the studies involved patients only in their sample ( Hardiman et al., 2016; Horstman et al., 2017; Naik et al., 2017; Powell et al., 2009; Uzun et al., 2011; Williams, 2008) with one quantitative study involving patients' family members and nurses (Sayin \& Aksoy, 2012). The number of participants for each study ranged from 7 to 430 for all seven studies.. Three 
studies were conducted in the USA (Hardiman et al., 2016; Horstman et al., 2017; Naik et al., 2017), two from Turkey (Sayin \& Aksoy, 2012; Uzun et al., 2011), one from Canada (Williams, 2008), and one from the United Kingdom (Powell et al., 2009).

3.2. Who delivers the discharge education provided to general surgical patients?

Discharge education was solely delivered by nurses in two studies (Horstman et al., 2017; Williams, 2008). In three other studies, healthcare professionals such as physicians, surgeons, general practitioners and nurses were responsible for delivering education to the patients (Hardiman et al., 2016; Powell et al., 2009; Sayin \& Aksoy, 2012; Uzun et al., 2011).

\subsection{When is the discharge education delivered to general surgical patients?}

Timing for the delivery of discharge education varied across studies. Three of the studies discussed education delivered preoperatively (Hardiman et al., 2016; Powell et al., 2009; Sayin \& Aksoy, 2012), in two studies, discharge education was delivered postoperatively (Hardiman et al., 2016; Powell et al., 2009), four studies discussed education delivered prior to discharge from hospital (Hardiman et al., 2016; Horstman et al., 2017; Uzun et al., 2011; Williams, 2008) and in one study, education was delivered two weeks after discharge from hospital (Naik et al., 2017). In two other studies, education was delivered at several time points including preoperatively, postoperatively (Powell et al., 2009) and at discharge (Hardiman et al., 2016).

3.4. What is the content of the discharge education provided to general surgical patients? Discharge education delivered as an intervention was illustrated in three studies (Hardiman et al., 2016; Horstman et al., 2017; Naik et al., 2017). These education inventions included a checklist for stoma care (Hardiman et al., 2016), a discharge warning tool for colorectal patients (Naik et al., 2017), and a post discharge care plan about medications, physical activity, post-operative complications and follow up care (Horstman et al., 2017). Of these three studies, two were individualised education developed according to patients' learning needs (Horstman et al., 2017; Naik et al., 2017). Discharge education provided in other studies without an intervention included disease and non-disease teaching about wound care, postoperative complications, medications, pain management, nutrition, physical activity and post op follow-up care (Powell et al., 2009; Sayin \& Aksoy, 2012; Uzun et al., 2011; Williams, 2008). 
3.5. How is the discharge education delivered to general surgical patients?

The majority of discharge education material was mostly presented to patients verbally (Powell et al., 2009; Sayin \& Aksoy, 2012; Uzun et al., 2011), in group discussion with family members present (Sayin \& Aksoy, 2012) and accompanied with education materials such as a booklet or folder of information resources as an adjunct to the verbal instructions (Hardiman et al., 2016; Horstman et al., 2017; Naik et al., 2017; Williams, 2008). Visual modes of discharge education such as pictures and models were discussed in one study (Sayin \& Aksoy, 2012).

\subsection{Quality assessment}

The methodological quality of the studies ranged from low to high. A common limitation among quantitative studies was the lack of discussion of the validity and reliability with data collection instruments (Hardiman et al., 2016; Sayin \& Aksoy, 2012). Sampling strategies and response rates were not reported in one study (Uzun et al., 2011), and the type of instruments administered were not discussed in another study (Hardiman et al., 2016). The lack of reflexivity was the most common limitation of the included qualitative studies (Horstman et al., 2017; Naik et al., 2017).

\subsection{Inductive analysis}

The inductive analysis of the seven studies revealed four themes: quality of discharge education influences its uptake, health care professionals' perceptions of their role in the delivery of discharge education to patients, patients' preferences for education delivery and patients' participation in their self-care.

\subsubsection{Quality of discharge education influences its uptake}

The quality of self-care education delivered to participants to manage their recovery at home following discharge was found to impact their recovery and outcomes. Discharge education delivered that was rushed, inadequate or delivered at an inopportune time such as when patients were still drowsy (following anaesthetic extubation) led to poor information uptake (Powell et al., 2009; Williams, 2008). Vital information not effectively delivered or processed by patients contributed to patients' knowledge deficits, causing confusion and uncertainty in the management of post discharge care (Powell et al., 2009; Williams, 2008). Patients felt that they were 'sent home blindly' and often had to access a medical facility unexpectedly 
after discharge as they lacked the skills and knowledge to identify or assess their postoperative condition at home (Powell et al., 2009; Williams, 2008). Patients in the study by Williams and colleagues (Williams, 2008) who did not receive education on pain and wound management had to make a non-routine visits to a health care facility after discharge, as they were unsure of how to ascertain whether something was 'abnormal'.

Comprehensive and adequate education delivered using interventions such as a self-care checklist and assessment tools empowered patients with the knowledge and confidences to take charge of their recovery by knowing the appropriate actions to take when required (Hardiman et al., 2016; Horstman et al., 2017; Naik et al., 2017). Patients who perceived that discharge education delivered was sufficient did not experience any concerns following discharge and were less likely to access a health care facility (Powell et al., 2009). In fact, the implementation of a self-care checklist developed by Hardiman and colleagues (2016) showed an improvement in readmission rates in the intervention group.

\subsubsection{Health care professionals' perceptions of their role in the delivery of discharge education to patients}

The second theme 'health care professionals' perceptions of their role in the delivery of discharge education to patients' described patients' information needs and their understanding of information given by the health care professionals was not always assessed (Williams, 2008). Patients were not asked what information they already knew and what they might need to care for themselves at home (Williams, 2008). About $80 \%$ of the Turkish nurses interviewed in the study by Sayin and colleagues (2012) acknowledged that discharge education is often inadequately delivered to patients and their families as they do not regard discharge education as the primary or mandatory role of nurses. Priorities were often placed on other aspects of the surgical process such as pre-operative physical preparation for surgery and postoperative symptoms management rather than discharge education (Sayin \& Aksoy, 2012; Uzun et al., 2011). Poor education delivery by nurses was attributed to insufficient staffing, the lack of time and knowledge to deliver appropriate education to the patients. However, the reasons for poor education delivery were explored in only one of the seven papers identified (Sayin \& Aksoy, 2012).

\subsubsection{Patients' preferences for education delivery}


The third theme described patients' preferences for discharge education to be delivered. Patients had preferences around the presentation of information delivered. The use of understandable language and the presentation of the education delivery was important in conveying the information (Horstman et al., 2017; Naik et al., 2017; Sayin \& Aksoy, 2012). Patients preferred the information to be printed, self-explanatory, to the point and easy to understand as medical jargon made it difficult to understand the content of the information (Sayin \& Aksoy, 2012). The majority of the patients suggested that both written information and oral education should be provided to improve patients' knowledge (Horstman et al., 2017; Sayin \& Aksoy, 2012; Williams, 2008). At times, discharge education was discussed several weeks before surgery during patients' pre-admission appointment (Sayin \& Aksoy, 2012) . In these cases, the content of this education was often 'forgotten' after the patients was discharged from hospital because there were no written materials to remind patients what was discussed. Patients may be unaware of the signs and symptoms to look for post discharge. Printed information on self-care provided to patients was referred to at least four times at home after they were discharged in one of the studies (Horstman et al., 2017).

In the delivery of information, patients favoured certain topics for discussion during discharge education sessions. Patients preferred to be given more information on pain management and wound care post discharge. The subscales "treatment and complications" and 'activities of daily living' were considered important (Uzun et al., 2011). Patients prioritised a list of the activities based on what they could or could not perform after discharge as important over other aspect of their recovery (Sayin \& Aksoy, 2012; Uzun et al., 2011; Williams, 2008).

The attending physician was usually the preferred source of information after surgery even though education was delivered by different health care professionals throughout patients' surgical journey. Physician discharge education had a strong influence on patients' decisions and advice given in relation to analgesic use and resuming normal activities was adhered by patients to avoid any post-operative complications (Powell et al., 2009; Sayin \& Aksoy, 2012; Uzun et al., 2011).

\subsubsection{Patients' participation in their self-care}

The fourth theme illustrates patients' participation in their self-care. In this review, patients demonstrated active participation in their care using information seeking behaviours (Powell 
et al., 2009; Williams, 2008), asking questions (Williams, 2008), clarifying information and undertaking decision making (Powell et al., 2009). Other patients undertook a more passive role in participation, by adhering to health care professionals' instructions. Medical instructions by physicians to limit activities were followed to avoid any post-operative complications (Horstman et al., 2017; Powell et al., 2009) . Patients participated in care by asking questions, expressing 'their responsibility to ask questions if the information was not volunteered during nurses' education sessions (Williams, 2008). In the study by Williams (2008), patients showed a desire for more information, commenting that "they would have liked to know how to 'clean the incision', when the 'coverings' could be removed and when the 'stitches' should come out".

Patients used other sources of informal information gathering about their self-care including the internet or past experience of others (Powell et al., 2009). However, patients were wary about the quality and accuracy of the information gathered online. Some patients used these sources to understand their condition and this enabled them to communicate with health care professionals when discussing their medical conditions (Powell et al., 2009). Patients demonstrated empowering behaviours that enabled them to participate in their care. Patients took accountability for their discharge process by demonstrating comprehension of the discharge education. They were able to give detailed descriptions such as medication instructions, directions of how to refill medications, activity restrictions, identifying warning signs and symptoms, and future appointments (Horstman et al., 2017). They were also able to assess their physical condition and identify appropriate actions such as going to the emergency room or calling a medical provider for specific warning signs and symptoms (Horstman et al., 2017; Williams, 2008).

\section{Discussion}

The aim of this systematic mixed studies review was to identify who, what, why and how discharge education has been delivered to general surgical patients. In this systematic mixed studies review, our findings indicate that the structure and quality of the discharge education has an impact on patients' recovery at home. In another study, patients and family not involved in decisions regarding their recovery due to poor discharge preparation often resulted in knowledge deficits and unsuccessful coping with demands of self-management at home (Weiss et al., 2010). Perceptions of discharge readiness by nurses have been associated with unplanned readmission or ED visit within 30 days after hospital discharge (Weiss et al., 
2010). Patients' perceptions of readiness to be discharge may be different from their health care provider evaluation (Reiley et al., 1996). Nurses often reported greater levels of patients' readiness to be discharged than patients themselves by underestimating patients' post discharge functional ability and overestimating their knowledge of the post discharge plan (Reiley et al., 1996; Weiss et al., 2010). Assessing patients' readiness to be discharged from the hospital has been identified as a central component of the discharge planning to ensure that patients' educational needs are met prior to discharge. Quality discharge teaching places patients in a state of readiness and prepares them for the successful management of their care and recovery at home (Weiss et al., 2007). Further training should be emphasised on the quality of the delivery of discharge teaching by health care professionals to ensure that patients are prepared for the transition to recovery at home.

Our review findings suggest that patients' participation is characterised by information seeking behaviour, asking questions, clarifying information and decision-making. To be able to participate in self-care, patients are required to be well informed of their illness and treatments options. Health care professionals should not assume that patients will ask questions or volunteer information. Our review findings indicate that further information was not offered by nurses if this was not requested by patients (Williams, 2008). Effective communication between patients and health care professionals is essential to effective discharge planning (Carroll et al., 2007).

Information seeking behaviour such as internet searching has resulted in more patients turning to online information as their first source of health information (Graffigna et al., 2017). With this knowledge, patients felt more empowered and were inclined to be involved in their health decision making by discussing their conditions with their physicians as evidenced in our review (Powell et al., 2009). This finding is supported by the study that found patients' internet use frequency for health information is positively associated with overall preference for health information and participation in decision making (Xie et al., 2013).

Powell and colleagues (2009) study was the only article in this review that discussed patients' active participation in the decision making process about surgery, analgesic use, taking actions and returning to activity. Shared decision making has been linked with improved patients' satisfaction. Surgical patients who are better informed and have a clear 
preference for surgery have better outcomes post operatively (Arterburn et al., 2011; Sepucha et al., 2017) Various models of patients' participation have been proposed to enable health care professionals to communicate better with their patients and involved them in the decision making process of their care. The imbalance in physician patient relationship is often unavoidable as the patient is more likely to remain passive in the decision making process as they feel unwell and vulnerable (Tobiano, et al., 2016a). This was evidenced in our review when patients' felt intimidated to make decisions and followed physician's recommendations even when the recommendations went against what the patients' believed to be best for them or what they preferred. Health care professionals, particularly physicians are perceived as the expert source of knowledge and would contribute to a successful recovery (Powell et al., 2009). The study by Tobiano and colleagues (2015) discussed the challenges of engaging patients in decision making when patients were unsure of the level of participation expected to undertake. Health care professionals, particularly physicians' recommendations have a strong influence on medical decision making and can prevent patients from making decision that goes against their preference. Engaging in genuine and meaningful dialogue between patients and health care professionals has been proposed as a means of preventing patients' non-participation in care (Eldh et al., 2006; Tobiano et al., 2016b).

\subsection{Standardised and tailored discharge education}

Our review demonstrated that educational materials delivered as individualised interventions were found to be beneficial to patients as they actively responded to the teaching. With the knowledge acquired, patients were able to appraise and identify their condition leading to a reduction in hospital readmission rates and complications. This finding is consistent with other reviews suggesting that individualised or tailored education was more effective than standardised education (Fredericks et al., 2010; Veronovici, 2014) .Tailored or individualised education is any educational intervention that uniquely addresses a person's learning needs (Fredericks \& Yau, 2013). The kind and amount of information patients seek may vary among patients. Fredericks et al. (2010) recommended that education design should include both individualised educational interventions and use of multiple media to reflect the learning needs of the individual as this approach would be more memorable.

\subsection{Timing and dose}


Discharge education delivered to patients at different time points and the frequency of discharge sessions has an impact on patients' understanding of discharge education delivered. Timing of education delivery is crucial for patients to get the most benefit. Our review examined discharge education delivered at different timings and the doses though we did not identify if education delivered preoperatively or postoperatively was associated with patients' post discharge recovery. Fredericks (2009) examined timing of an education intervention delivered to coronary artery bypass graft patients and found that education delivered prior to, or after discharge made no difference in patients' knowledge of self-care behaviours.

Discharge processes that commence at the time of the patient's admission and continue during their stay demonstrated significant reduction in 30 day mortality rates for patients with acute myocardial infarction. This finding is supported by several reviews (Fredericks et al., 2010; Ronco et al., 2012) suggesting that individualised education scheduled early and delivered using several doses over a period of time, is essential to enhance patients' overall knowledge for successful self-management of recovery at home.

\subsection{Limitations}

We acknowledge several limitations to this mixed studies review. This review was informed a priori by defined inclusion and exclusion criteria, with searches conducted in scholarly databases. While every effort has been undertaken to conduct a comprehensive search, it is possible that some studies might have been missed. For example, we have added the Boolean operator NOT "day surgery" or "ambulatory surgery" as we wanted to exclude these types of procedures and this could have narrowed the search and caused some potential studies to be missed. Second, of the quantitative studies included, there were few empirical studies of individualised discharge education interventions. Some of the studies were exploratory and relied primarily on self-report. These studies were selected based on the aims of identifying the types of discharge education delivered to general surgery patients and included studies were intended to provide a holistic view of education provided. Lastly, a sensitivity analysis was not performed due to the limited number of studies identified from this review and a qualitative analysis was used to synthesis the data. Notwithstanding, a clear and transparent description of the review process was conducted and discussed.

\section{Conclusions}


Our systematic review highlights the importance of discharge education and its effectiveness to general surgical patients. The quality of discharge education has an influence on patients' participation in their management of care post discharge from the hospital. Assessing patients' preparedness for discharge is an essential component of discharge planning process. Health care professionals often fail to assess if discharge education given to patients has been understood. Poor education delivery may be attributed to insufficient staffing, the lack of time and sufficient knowledge of the discharge process. The presentation, timing and frequency of discharge education were important aspects in conveying the information. Tailored education reflecting the learning needs of the patients using multiple media delivered via multiple doses enhanced patient's overall knowledge for successful recovery post discharge. Patients demonstrated engagement in their care using behaviours centred on information seeking, and undertaking decision making regarding their recovery process to gain an understanding of their treatment and symptoms. The scarcity of recent literature in discharge education indicates that the quantity of evidence regarding discharge education interventions in general surgery patients is low and further work in this area is needed. Further research is required to identify evidence informed strategies to improve the delivery of discharge education to patients, and hence, enhance the surgical patient's experience.

Acknowledgements

The authors would like to acknowledge the support of Claudia Bull in assisting with quality assessment and data extraction of the included articles with the first author. 


\section{$\underline{\text { References }}$}

Arterburn, D.E., Westbrook, E.O., Bogart, T.A., Sepucha, K.R., Bock, S.N., Weppner, W.G., 2011. Randomized Trial of a Video-Based Patient Decision Aid for Bariatric Surgery. Obesity. 19 (8), 1669-1675. doi:10.1038/oby.2011.65

Carroll, A., Dowling M., 2007. Discharge planning: communication, education and patient participation. Br J Nurs. 16 (14), 882-886. doi:10.12968/bjon.2007.16.14.24328

Carter, J., Philp, S., Wan, K.M., 2016. Optimising recovery after surgery: Predictors of early discharge and hospital readmission. Aust N Z J Obstet Gynaecol. 56 (5), 489-495. doi:10.1111/ajo.12484

Cooke, A., Smith, D., Booth, A., 2012. Beyond PICO: The SPIDER Tool for Qualitative Evidence Synthesis. Qual Health Res. 22 (10), 1435-1443. doi:10.1177/1049732312452938

Dawes, A.J., Sacks, G.D., Russell, M.M., Lin, A.Y., Maggard-Gibbons, M., Winograd, D., Chung, H.R., Hiatt, J.R., Ko, C., 2014. Preventable readmissions to surgical services: lessons learned and targets for improvement. J Am Coll Surg. 219 (3), 382-389. doi:10.1016/j.jamcollsurg.2014.03.046

Eldh, A.C., Ehnfors, M., Ekman, I., 2006. The meaning of patient participation for patients and nurses at a nurse-led clinic for chronic heart failure. Eur J Cardiovasc Nurs. 5 (1), 45-53. doi:10.1016/j.ejcnurse.2005.06.002

Fredericks, S., 2009. Timing for delivering individualized patient education intervention to Coronary Artery Bypass Graft patients: An RCT. Eur J Cardiovasc Nurs. 8 (2), 144150. doi:10.1016/j.ejcnurse.2008.10.007

Fredericks, S., Guruge, S., Sidani, S., Wan, T., 2010. Postoperative patient education: a systematic review. Clin Nurs Res. 19 (2), 144-164. doi: 10.1177/1054773810365994

Fredericks, S., Ibrahim, S., Puri, R., 2009. Coronary artery bypass graft surgery patient education: A systematic review. Prog in Cardiovasc Nurs. 24 (4), 162-168. doi:10.1111/j.1751-7117.2009.00055.x

Fredericks, S., Yau, T., 2013. Educational intervention reduces complications and rehospitalizations after heart surgery. West J Nurs Res. 35 (10), 1251-1265. doi:10.1177/0193945913490081

Graffigna, G., Barello, S., Bonanomi, A., Riva, G., 2017. Factors affecting patients' online health information-seeking behaviours: The role of the Patient Health Engagement (PHE) Model. Patient Educ Couns. 100 (10), 1918-1927. doi:10.1016/j.pec.2017.05.033

Griffith, R., 2016. What is Gillick competence? Hum Vaccin Immunother, 12 (1), 244-247. doi:10.1080/21645515.2015.1091548 
Hardiman, K.M., Reames, C.D., McLeod, M.C., Regenbogen, S.E., 2016. Patient autonomycentered self-care checklist reduces hospital readmissions after ileostomy creation. Surgery. 160 (5), 1302-1308. doi:10.1016/j.surg.2016.05.007

Henderson, A., Zernike, W., 2001. A study of the impact of discharge information for surgical patients. J Adv Nurs, 35 (3), 435-441. doi:10.1046/j.1365-2648.2001.01857.x

Hopewell, S., Clarke, M., Lefebvre, C., Scherer, R., 2007. Handsearching versus electronic searching to identify reports of randomized trials. Cochrane Database Syst Rev. 18 (2): MR000001. doi:10.1002/14651858.MR000001.pub2

Horstman, M. J., Mills, W.L., Herman, L.I., Cai, C., Shelton, G., Qdaisat, T., Berger, D.H., Naik, A.D., 2017. Patient experience with discharge instructions in postdischarge recovery: a qualitative study. BMJ Open. 7 (2). doi:10.1136/bmjopen-2016-014842

Jack, B.W., Chetty, V.K., Anthony, D., Greenwald, J.L., Sanchez, G.M., Johnson, A.E., Forsythe, S.R., O'Donnell, J.k., Paasche-Orlow, M.K., Manasseh, C., Martin, S., Culpepper, L., 2009. A reengineered hospital discharge program to decrease rehospitalization: a randomized trial. Ann Intern Med. 150 (3), 178-187.

Jencks, S.F., Williams, M.V., Coleman, E.A., 2009. Rehospitalizations among Patients in the Medicare Fee-for-Service Program. N Engl J Med. 360 (14), 1418-1428. doi:10.1056/NEJMsa0803563

Kassin, M.T., Owen, R.M., Perez, S.D., Leeds, I., Cox, J.C., Schnier, K., Sadiraj, V., Sweeney, J.F., 2012. Risk factors for 30-day hospital readmission among general surgery patients. J Am Coll Surg. 215 (3), 322-330. doi:10.1016/j.jamcollsurg.2012.05.024

Kazaure, H.S., Roman, S.A., Sosa, J.A. 2012. Association of postdischarge complications with reoperation and mortality in General Surgery. Arch Surg. 147 (11), 1000-1007. doi:10.1001/2013.jamasurg.114

Lin, C.J., Cheng, S.J., Shih, S.C., Chu, C.H., Tjung, J.J., 2012. Discharge Planning. Int J of Gerontol. 6 (4), 237-240. doi:https://doi.org/10.1016/j.ijge.2012.05.001

Lithner, M., Klefsgard, R., Johansson, J., Andersson, E., 2015. The significance of information after discharge for colorectal cancer surgery-a qualitative study. BMC Nurs. 14, 36. doi:10.1186/s12912-015-0086-6

Loubani, M., Mediratta, N., Hickey, M.S., Galiñanes, M., 2000. Early discharge following coronary bypass surgery: is it safe? Eur J Cardiothorac Surg. 18 (1), 22-26. doi:10.1016/S1010-7940(00)00467-X

Louw, A., Diener, I., Butler, D.S., Puentedura, E.J., 2013. Preoperative education addressing postoperative pain in total joint arthroplasty: Review of content and educational delivery methods. Physiother Theory Pract. 29 (3), 175-194. doi:10.3109/09593985.2012.727527 
McMurray, A., Johnson, P., Wallis, M., Patterson, E., Griffiths, S., 2007. General surgical patients' perspectives of the adequacy and appropriateness of discharge planning to facilitate health decision-making at home. J Clin Nurs. 16 (9), 1602-1609. doi:10.1111/j.1365-2702.2006.01725.x

Merkow, R.P., Ju, M.H., Chung, J.W., Hall, B.L., Cohen, M.E., Williams, M.V., Tsai, T.C. Ko, C.Y., Bilimoria, K.Y., 2015. Underlying reasons associated with hospital readmission following surgery in the united states. JAMA. 313 (5), 483-495. doi:10.1001/jama.2014.18614

Moher, D., Liberati, A., Tetzlaff, J., Altman, D.G., The, P.G., 2009. Preferred reporting items for systematic reviews and meta-analyses: The PRISMA statement. PLoS Med. 6 (7). doi:10.1371/journal.pmed.1000097

Naik, A.D., Horstman, M.J., Li, L.T., Paasche-Orlow, M.K., Campbell, B., Mills, W.L., Herman, L.I., Anaa, D.A., Trautner, B.W., Berger, D.H., 2017. User-centered design of discharge warnings tool for colorectal surgery patients. J Am Med Inform Assoc. 24 (5), 975-980. doi:10.1093/jamia/ocx018

Pieper, B., Sieggreen, M., Freeland, B., Kulwicki, P., Frattaroli, M., Sidor, D., Palleschi M.T., Bednarski, D., Garretson, B., 2006. Discharge information needs of patients after surgery. J Wound Ostomy and continence nurs. 33 (3), 281-290. doi:10.1097/00152192-200605000-00009

Pieper, B., Sieggreen, M., Nordstrom, C., Kulwicki, P., Freeland, B., Palleschi, M.T., Sidor, D., Dednarski, D., Burns, J., Frattaroli, M., 2006. Bariatric surgery: patient incision care and discharge concerns. Ostomy Wound Manage. 52 (6), 48-52.

Pluye, P., Gagnon, M.P., Griffiths, F., Johnson-Lafleur, J., 2009. A scoring system for appraising mixed methods research, and concomitantly appraising qualitative, quantitative and mixed methods primary studies in Mixed Studies Reviews. Int J Nurs Stud. 46 (4), 529-546. doi:10.1016/j.ijnurstu.2009.01.009

Pluye, P., Hong, Q.N. 2014. Combining the power of stories and the power of numbers: mixed methods research and mixed studies reviews. Annu Rev Public Health, 35, 29-45. doi: 10.1146/annurev-publhealth-032013-182440

Pluye, P., Robert, E., Cargo, M., Bartlett, G., O’Cathain, A., Griffiths, F., Boardman, F., Gagnon, M.P., Rousseau, M.C., 2011. Proposal: A Mixed Methods Appraisal Tool for Systematic Mixed Studies Reviews.

http://mixedmethodsappraisaltoolpublic.pbworks.com/ (accessed 01.11.17).

Polster, D. (2015). Preventing readmissions with discharge education. J Nurs Manag. 46 (10), 37-38. doi: 10.1097/01.NUMA.0000472592.47774.5b

Powell, R., McKee, L., Bruce, J., 2009. Information and behavioural instruction along the health-care pathway: The perspective of people undergoing hernia repair surgery and the role of formal and informal information sources. Health Expect. 12 (2), 149-159. 
Reiley, P., Iezzoni, L.I., Phillips, R., Davis, R.B., Tuchin, L.I., Calkins, D., 1996. Discharge planning: comparison of patients and nurses' perceptions of patients following hospital discharge. Image J Nurs Sch. 28 (2), 143.

Ronco, M., Iona, L., Fabbro, C., Bulfone, G., Palese, A., 2012. Patient education outcomes in surgery: a systematic review from 2004 to 2010. Int J Evid Based Healthc. 10 (4), 309-323. doi:10.1111/j.1744-1609.2012.00286.x

Sayin, Y., Aksoy, G., 2012. The nurse's role in providing information to surgical patients and family members in Turkey: a descriptive study. AORN J. 95 (6), 772-787. doi:10.1016/j.aorn.2011.06.012

Sepucha, K., Atlas, S.J., Chang, Y., Dorrwachter, J., Freiberg, A., Mangla, M., Rubash, H.E., Simmons, L.H. Cha, T., 2017. Patient decision aids improve decision quality and patient experience and reduce surgical rates in routine orthopaedic care. J Bone Joint Surg Am. 99 (15), 1253-1260. doi:10.2106/JBJS.16.01045

Sivarajan, N. Ganesan, R., 2012. Study on discharge information for surgical patients. Indian J Sci Technol. 5 (7), 3013-3016.

The American Board of Surgery, 2017. Specialty of General Surgery Defined. http://www.absurgery.org/default.jsp?aboutsurgerydefined (accessed 09.12.17)

Taylor, D.M., Cameron, P.A., 2000. Discharge instructions for emergency department patients: what should we provide? J Accid Emerg Med. 17 (2), 86-90. doi: 10.1136/emj.17.2.86

Thomas, J., Harden, A., 2008. Methods for the thematic synthesis of qualitative research in systematic reviews. BMC Med Res Methodol. 8 (1), 45-45. doi:10.1186/1471-2288-845

Tobiano, G., Marshall, A., Bucknall, T., Chaboyer, W., 2015. Patient participation in nursing care on medical wards: an integrative review. Int J Nurs Stud. 52 (6). 1107-1120. doi: 10.1016/j.ijnurstu.2015.02.010.

Tobiano, G., Bucknall, T., Marshall, A., Guinane, J., Chaboyer, W., 2016a. Patients' perceptions of participation in nursing care on medical wards. Scand J Caring Sci. 30 (2) 260-270. doi: 10.1111/scs.12237

Tobiano, G., Marshall, A., Bucknall, T., Chaboyer, W., 2016b. Activities patients and nurses undertake to promote patient participation.. J Nurs Scholarsh. 48 (4), 362-370. doi: 10.1111/jnu.12219

Uzun, O., Ucuzal, M., Inan, G., 2011. Post-discharge learning needs of General Surgery patients. Pak J Med Sci. 27 (3), 634-637.

Veronovici, N.R., 2014. Discharge education to promote self-management following cardiovascular surgery: An integrative review. Eur J of Cardiovasc Nurs. 13 (1), 2231 . 
Weiss, M., Yakusheva, O., Bobay, K., 2010. Nurse and patient perceptions of discharge readiness in relation to postdischarge utilization. Med Care. 48 (5), 482-486. doi:10.1097/MLR.0b013e3181d5feae

Weiss, M.E., Piacentine, L.B., Lokken, L., Ancona, J., Archer, J., Gresser, S., Holmes, S., Toy, A., Vega-Stromberg, T., 2007. Perceived readiness for hospital discharge in adult medical-surgical patients. Clin Nurse Spec. 21 (1), 31-42. doi:10.1097/00002800-200701000-00008

Williams, B., 2008. Supporting self-care of patients following general abdominal surgery. $\mathbf{J}$ Clin Nurs. 17 (5), 584-592. doi:10.1111/j.1365-2702.2006.01857.x

Xie, B., Wang, M., Feldman, R., Zhou, L., 2013. Internet use frequency and patient-centered care: measuring patient preferences for participation using the health information wants questionnaire. J Med Internet Res. 15 (7), 140-156. doi:10.2196/jmir.2615 


\section{Accepted Manuscript}

Title: Discharge education delivered to general surgical patients in their management of recovery post discharge - a systematic mixed studies review

Authors: Evelyn Kang, Brigid M. Gillespie, Geogia Tobiano, Wendy Chaboyer

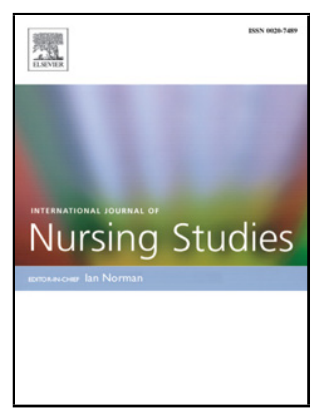

PII: S0020-7489(18)30158-5

DOI:

Reference: https://doi.org/10.1016/j.ijnurstu.2018.07.004

To appear in:

Received date: $\quad$ 19-2-2018

Revised date: $\quad$ 4-7-2018

Accepted date: $\quad 4-7-2018$

Please cite this article as: Kang E, Gillespie BM, Tobiano G, Chaboyer W, Discharge education delivered to general surgical patients in their management of recovery post discharge - a systematic mixed studies review, International Journal of Nursing Studies (2018), https://doi.org/10.1016/j.ijnurstu.2018.07.004

This is a PDF file of an unedited manuscript that has been accepted for publication. As a service to our customers we are providing this early version of the manuscript. The manuscript will undergo copyediting, typesetting, and review of the resulting proof before it is published in its final form. Please note that during the production process errors may be discovered which could affect the content, and all legal disclaimers that apply to the journal pertain. 